Prepared in cooperation with the Bureau of Reclamation

\title{
Using Broad Landscape Level Features to Predict Redd Densities of Steelhead Trout (Oncorhynchus mykiss) and Chinook Salmon (Oncorhynchus tshawytscha) in the Methow River Watershed, Washington
}

Open-File Report 2013-1232 



\section{Using Broad Landscape Level Features to Predict Redd Densities of Steelhead Trout (Oncorhynchus mykiss) and Chinook Salmon (Oncorhynchus tshawytscha) in the Methow River Watershed, Washington}

By Jason G. Romine, Russell W. Perry, and Patrick J. Connolly

Prepared in cooperation with the Bureau of Reclamation

Open-File Report 2013-1232

U.S. Department of the Interior

U.S. Geological Survey 


\section{U.S. Department of the Interior \\ SALLY JEWELL, Secretary}

\section{U.S. Geological Survey \\ Suzette M. Kimball, Acting Director}

U.S. Geological Survey, Reston, Virginia: 2013

For more information on the USGS-the Federal source for science about the Earth, its natural and living resources, natural hazards, and the environment-visit http://www.usgs.gov or call 1-888-ASK-USGS

For an overview of USGS information products, including maps, imagery, and publications, visit $h t t p: / / w w w . u s g s . g o v / p u b p r o d$

To order this and other USGS information products, visit $h$ ttp://store.usgs.gov

Suggested citation:

Romine, J.G., Perry, R.W., and Connolly, P.J., 2013, Using broad landscape level features to predict redd densities of steelhead trout (Oncorhynchus mykiss) and Chinook Salmon (Oncorhynchus tshawytscha) in the Methow River watershed, Washington: U.S. Geological Survey Open-File Report 2013-1232, 22 p., http://pubs.usgs.gov/of/2013/1232/.

Any use of trade, product, or firm names is for descriptive purposes only and does not imply endorsement by the U.S. Government.

Although this report is in the public domain, permission must be secured from the individual copyright owners to reproduce any copyrighted material contained within this report. 


\section{Contents}

Abstract
Introduction .
Description of Study Area
Description of Data and Models.
Spatial Data
Discharge
Redd Data
Models
Steelhead Trout
Spring Chinook Salmon
Discussion
Acknowledgments
References Cited

\section{Figures}

Figure 1. Predicted mean annual redd density (redds per kilometer) for steelhead trout in the Methow River watershed, Washington

Figure 2. Predicted and observed redd densities for steelhead trout, Method River watershed, Washington, 2005-07 and 2009

Figure 3. Relationship (solid black lines) between mean annual discharge of the Methow River at Twisp, Wash. (U.S. Geological Survey stream gage No. 12449500) and observed mean annual redd densities for (a) steelhead trout, and (b) spring Chinook salmon..

Figure 4. Predicted mean annual redd density (redds per kilometer) for spring Chinook salmon in the Methow River watershed, Washington ....

Figure 5. Predicted and observed redd densities for spring Chinook salmon, Methow River watershed, Washington, 2005-09

\section{Tables}

Table 1. Water body characteristics for the Methow River watershed, Washington.

Table 2. Characteristics used to determine land cover type for each reach, Methow River watershed, Washington.

Table 3. Primary (a) and secondary (b) rock types and associated number of reaches for the Methow River watershed, Washington

Table 4. Single-variable mixed models fit to steelhead trout redd data, Methow River watershed, Washington.

Table 5. Model coefficient values for each variable in the best fit model for steelhead trout, Methow River watershed, Washington

Table 6. Model selection results for mixed models predicting steelhead trout redd density, Methow River watershed, Washington

Table 7. Single -variable models fit to spring Chinook salmon data, Methow River watershed, Washington 
Table 8. Model coefficient values for each variable in the best fit model for spring Chinook salmon, Methow River watershed, Washington

Table 9. Model selection results for mixed models predicting spring Chinook salmon redd density, Methow River watershed, Washington

\section{Conversion Factors and Datum}

\section{Conversion Factors}

\begin{tabular}{lll}
\hline Multiply & By & To obtain \\
\hline meter $(\mathrm{m})$ & Length & \\
kilometer $(\mathrm{km})$ & 3.281 & foot $(\mathrm{ft})$ \\
kilometer $(\mathrm{km})$ & 0.6214 & mile (mi) \\
meter $(\mathrm{m})$ & 0.5400 & mile, nautical (nmi) \\
\hline & 1.094 & yard (yd) \\
\hline square kilometer $\left(\mathrm{km}^{2}\right)$ & Area & \\
\hline & 0.3861 & square mile $\left(\mathrm{mi}^{2}\right)$ \\
\hline cubic meter per second $\left(\mathrm{m}^{3} / \mathrm{s}\right)$ & Flow rate & acre-foot per day \\
& 70.07 & $($ acre-ft/d) \\
cubic meter per second $\left(\mathrm{m}^{3} / \mathrm{s}\right)$ & & cubic foot per second \\
& 35.31 & $\left(\mathrm{ft}^{3} / \mathrm{s}\right)$ \\
cubic meter per second $\left(\mathrm{m}^{3} / \mathrm{s}\right)$ & & million gallons per day \\
& 22.83 & $($ Mgal $/ \mathrm{d})$ \\
\hline
\end{tabular}

\section{Datum}

Horizontal coordinate information is referenced to the North American Datum of 1983 (NAD 83). Altitude, as used in this report, refers to distance above the vertical datum. 


\title{
Using Broad Landscape Level Features to Predict Redd Densities of Steelhead Trout (Oncorhynchus mykiss) and Chinook Salmon (Oncorhynchus tshawytscha) in the Methow River Watershed, Washington
}

By Jason G. Romine, Russell W. Perry, and Patrick J. Connolly

\begin{abstract}
We used broad-scale landscape feature variables to model red densities of spring Chinook salmon (Oncorhynchus tshawytscha) and steelhead trout (Oncorhynchus mykiss) in the Methow River watershed. Redd densities were estimated from redd counts conducted from 2005 to 2007 and 2009 for steelhead trout and 2005 to 2009 for spring Chinook salmon. These densities were modeled using generalized linear mixed models. Variables examined included primary and secondary geology type, habitat type, flow type, sinuosity, and slope of stream channel. In addition, we included spring effect and hatchery effect variables to account for high densities of redds near known springs and hatchery outflows. Variables were associated with National Hydrography Database reach designations for modeling redd densities within each reach. Reaches were assigned a dominant habitat type, geology, mean slope, and sinuosity. The best fit model for spring Chinook salmon included sinuosity, critical slope, habitat type, flow type, and hatchery effect. Flow type, slope, and habitat type variables accounted for most of the variation in the data. The best fit model for steelhead trout included year, habitat type, flow type, hatchery effect, and spring effect. The spring effect, flow type, and hatchery effect variables explained most of the variation in the data. Our models illustrate how broad-scale landscape features may be used to predict spawning habitat over large areas where fine-scale data may be lacking.
\end{abstract}

\section{Introduction}

Modeling the influence of broad-scale landscape features on spawning habitat selection by anadromous salmonids is vital to informing conservation and restoration actions (Burnett and others, 2007). Fine-scale variation in environmental parameters such as gravel size or hyporheic flow have proven to be good predictors of spawning habitat selection (Geist and others, 2000); however, empirical data typically are not available for entire watersheds and may not be collected where spawning activity is absent. Thus, the fine-scale approach may be possible for small, restricted study areas, but is not feasible when modeling spawning habitat for entire watersheds (Hughes and others, 2006; Miller and others, 2008). 
Broad-scale landscape features such as geomorphology or gradient have proven useful for predicting spawning habitat of salmonids in various watersheds (Steel and others, 2004; Burnett and others, 2007; Shallin-Busch and others, 2013). This is not surprising, given that the underlying forces that shape streams, rivers, and lakes in the Pacific Northwest are ultimately a consequence of the local geomorphology, which in turn, influences processes affecting spawning habitat quality (for example, sedimentation). Shallin-Busch and others (2013) used channel gradient, confinement, and width to estimate the quality of spawning habitat for fall Chinook salmon (Oncorhynchus tshawytscha) and found a positive relationship between spawner density and a habitat quality index. Burnett and others (2007) used the aforementioned parameters coupled with land ownership, use, and cover (that is, forested, open, etc.) to illustrate potential spawning habitat of salmonids in coastal Oregon streams. Steel and others (2004) found positive relationships between spawning density and geology, hillslope, and land cover type (that is, agricultural use, grassland, wetland, etc.) in the Willamette River watershed in Oregon.

Habitat restoration projects are abundant in the Pacific Northwest and typically focus on measures to restore salmonid habitat. One way to guide restoration efforts at the watershed level is to use a large-scale approach to identify factors that delineate "good" and "poor" spawning habitat. Restoration efforts in areas of poor spawning habitat are destined for failure, for this reason, by directing restoration efforts toward suitable areas with a high probability to be used, we can increase the likelihood that restoration efforts will be successful (Burnett and others, 2007).

The Methow River watershed in north-central Washington provides critical habitat for several salmonid species listed under the Endangered Species Act (ESA; National Marine Fisheries Service, 1999). Within the watershed, large-scale projects are underway to restore salmon populations. An ecosystem model is being developed to test hypotheses regarding the potential effects of restoration efforts. The model requires a spawning habitat component that estimates densities of spawners at the reach level as defined by the National Hydrography Dataset (NHD) (U.S. Geological Survey and others, 2011). We used a linear mixed-model approach to model relationships between redd densities for Chinook salmon and steelhead trout (Oncorhynchus mykiss) and broad-scale landscape features in the Methow River watershed. We used predictive variables such as geology (rock type), slope, land cover, flow type, and sinuosity within the models. The linear mixed-model approach is useful for its predictive capabilities and the potential to be scaled accordingly from the watershed to reach level as defined by the National Hydrography Dataset.

\section{Description of Study Area}

The Methow River watershed is located in north-central Washington and encompasses about 4,662 $\mathrm{km}^{2}$. The watershed is comprised of the Chewuch, Methow, and Twisp Rivers, all of which provide spawning habitat for ESA listed spring Chinook salmon and summer steelhead trout (O. mykiss). Mean annual discharge at Twisp is $38.88 \mathrm{~m}^{3} / \mathrm{s}(\mathrm{SD}=12.35)$. Altitudes in the watershed range from approximately 213 to $2,743 \mathrm{~m}$.

The Methow River watershed is a rift-block valley (Waitt, 1972) primarily characterized by Quaternary sediments, intrusive rocks, volcanic rocks, and sedimentary rocks (Stoffel and others, 1991). Bedrock underlays the basin and is thinly covered by sediments in most areas except for the major river valleys (Konrad and others, 2003). 
Land cover is characterized by evergreen forest in the middle altitudes consisting primarily of lodgepole pine (Pinus contorta), ponderosa pine (Pinus ponderosa), and Douglas fir (Psuedotsuga menziensii). Lower areas are primarily scrublands consisting of bitter brush (Purshia tridentata), big sagebrush (Artemisia tridentata), and various bunchgrass species.

\section{Description of Data and Models}

\section{Spatial Data}

Reach designations were those established by the NHD (U.S. Geological Survey and others, 2011). The NHD data used in the models consisted of 10,476 reaches, which averaged $0.73 \mathrm{~km}(\mathrm{SD}=0.88 \mathrm{~km})$ and ranged from 0.004 to $8.36 \mathrm{~km}$ in length. The NHD dataset used in the analyses was nhd24kst_1_17020008. Flow type ("FCODE", table 1) was used as a descriptive variable for type of flow. The primary flow type within the dataset was intermittent streams or rivers. The number of reaches designated as intermittent was an order of magnitude greater than perennial and artificial streams or paths. Each unique FCODE was used as a level of flow type in the model. Reaches without viable spawning habitat or reaches that were not accessible by fishes due to their flow type (that is, aqueducts and pipelines) were removed from the analyses.

Land coverage type was associated with each NHD reach by joining land cover data from the National Land Cover Database (NLCD) (Fry and others, 2011) with intersecting reaches (table 2). All geo-referencing was done using ArcMap ${ }^{\odot}$ 9.3.1. The dominant land cover type within each reach was then designated as that reach's land cover type for use in the models. Two slope metrics were included in our variable set - mean slope and critical slope percentage. Mean slope for each reach was calculated by extracting slope from a Digital Elevation Model (DEM) and referencing slope to reaches at $8-\mathrm{m}$ increments. Critical slope was calculated as the proportion of each reach where slope was less than 8 percent. Burnett and others (2007) suggested that gradients in excess of 7 percent were not suitable for steelhead spawning. Reach sinuosity (linear length from start to end of reach divided by actual length) was calculated from the NHD layer and included as sinuosity for each NHD designated reach. Both primary and secondary rock types were associated with reaches (table 3 ). The dominant geological rock types were associated with each reach as was done with land cover. Rock type data layers were provided by the U.S. Geological Survey (USGS) Mineral Resources Program (Ludington and others, 2005).

In addition to landscape level factors, two binomially distributed categorical factors were included. These were spring effect and hatchery effect. These terms were included to accommodate the order of magnitude difference in redd densities at these locations relative to all other areas. Some of the highest redd densities in the watershed were near Suspension Creek and the two hatcheries (Winthrop National Fish Hatchery and Methow Fish Hatchery near Winthrop, Wash.). Reaches adjacent to Suspension Creek on the Methow River were designated as "1" for spring effect, while all other reaches were designated as "0" for this effect All reaches adjacent to the Methow Hatchery and Winthrop Hatchery were designated as " 1 " for hatchery effect, while all other reaches were designated as "0" for this effect. 


\section{Discharge}

Mean annual discharge measured at Twisp (USGS stream gage No. 12449500) was included as a continuous predictor variable to accommodate potential observational errors in the redd count data. Count based observations of redd density likely underestimated the true density of redds, because all redds may not have been observable during a survey. Due to streambed mobilization, redds can be scoured or entombed with sediment during periods of high discharge, and redd counts then become more negatively biased (Montgomery and others, 1996; Jones, 2012). Mean annual discharge was used to account for this bias. To specifically examine this concern, we regressed redd density on mean annual discharge to explore the potential effect of discharge on redd counts.

\section{Redd Data}

We used redd data for steelhead trout collected in 2005-07 and 2009 by the Washington Department of Fish and Wildlife (WDFW). Redd data for spring Chinook salmon were collected from 2005 to 2009 by WDFW. Index areas were developed based on historical spawning data. Index areas were surveyed weekly throughout the spawning season (Snow and others, 2009). At the time of peak spawning, non-index areas also were surveyed. Redd counts in non-index areas were added to the redd counts in index areas for a total estimated redd count for each stream. Redd locations were recorded using a handheld Global Positioning System (GPS) unit. Redd densities were calculated for each NHD reach by creating a 75-m-radius buffer along the reach and truncated at the end of each reach for the NHD layer. Redd locations were then joined with this buffer to assign them to a specific reach. Annual redd densities per reach were then calculated as redds per kilometer.

\section{Models}

We used a linear mixed model approach similar to the methods of Steel and others (2004). All models were fit in R (R Development Core Team, 2011) using maximum-likelihood estimation (MLE) to enable model fit comparisons (Zuur and others, 2009). Redd densities were inflated by one and then log transformed, as their distribution was lognormal. We used Bayesian Information Criterion (BIC) to identify the best fit model (Schwarz, 1978). We used a backward step-wise strategy for model selection (Zuur and others, 2009). We initially fitted three models to redd density data. The three models were (1) a main effects model with all predictive variables, (2) a main effects model with all predictive variables with reach as the random intercept, and (3) a main effects model with all predictive variables with reach as the random intercept and year as the random slope. Random slope and intercept models were fit to the data to account for potential variation in redd density within reaches between years and potential differences in effects of landscape factors on redd density across the study area. The model with the lowest BIC value was selected and each predictor was then removed in an iterative process, one at a time, and each reduced model was compared to the full model using BIC (Schwarz, 1978). If the removal of a variable resulted in a lower BIC value, the variable was removed from the model. This process was repeated until removal of variables was no longer supported. Year was used as the random slope variable and reach was used as the random intercept. Model selection was again based on BIC. Akaike Information Criterion (AIC) was included in results for comparative purposes (Akaike, 1973). Residuals of the final model were examined to verify the assumption of homogeneity of variance (Zuur and others, 2009). In addition; single-variable mixed effects 
models with random slope and random intercept were fit to the data to examine which variables had the greatest influence on redd densities. Once the best fit model was selected, redd densities were predicted for each reach and year. Predicted redd densities were then joined with the NHD data, and mapped to gain insights from the predicted spatial distribution of redds throughout the watershed.

\section{Results}

\section{Steelhead Trout}

Single-variable mixed models for steelhead trout indicated that spring effect, flow type, and hatchery effect were the most important variables (tables 4 and 5). Year was included as the random slope term and reach was included as the random intercept. The spring effect singlevariable mixed model was 909 BIC units better than the next best model (table 4). After flow type and hatchery effect models, all other single-variable models accounted for similar amounts of variation in the data. Primary rock type and sinuosity models explained the least amount of variation in the data.

We present the top three models based on BIC in table 6. All other models had BIC values that were at least 100 units greater than these three models. MLE did not converge when primary rock type was included as a predictor; therefore primary rock type is not represented in the set of candidate models (table 6). The best fit model of redd density for steelhead trout included random effects, with a slope adjustment for year and an intercept adjustment for reach. Other predictive variables included in the best model were land cover type and flow type. Hatchery effect and spring effect also were retained in the model (table 6). High redd densities were predicted in the Suspension Creek area and several reaches in the Twisp River near Little Bridge Creek (fig. 1). The model fit the data well with only slight negative bias and approximately normal residuals (fig. 2); however, the model did predict occurrence of redds in reaches where they were not observed. Two patterns were apparent in reaches where redds were predicted, but not observed. In the first instance, redds were observed during low-flow years but not during high-flow years in the same reach. Steelhead trout mean annual redd density was negatively correlated to discharge (fig. $3 \mathrm{a}, \mathrm{r}^{2}=0.9065, p=0.032$ ), indicating that the discrepancy in predicted redd occurrence may be explained by observer error. In the second instance, redds were predicted to occur, but were not observed within the reach throughout the study period. This could be because predicted redds occurring in locations that were not sampled throughout the study period.

\section{Spring Chinook Salmon}

Single-variable mixed models for spring Chinook salmon redds indicated that flow type, slope, and land cover type were the most important variables (tables 7 and 8). Year, secondary rock type, and primary rock type all provided a worse fit to the data than the intercept-only model. Spring effect and hatchery effect models showed much less variation for the spring Chinook salmon data than for the steelhead trout data.

The best fit model for red density for Chinook salmon included sinuosity, critical slope, land cover type, flow type, and hatchery effect (table 9), with reach a slope adjustment for year and an intercept adjustment for reach. The highest redd densities were predicted to occur in the Upper Methow and Chewuch Rivers upstream of Winthrop (fig. 4). The model provided a good 
fit to the data with slight negative bias (fig. 5). Similar to the steelhead trout model, the spring Chinook salmon model predicted redds to occur in reaches where redds were either not observed in all years or were not observed in some years. Sinuosity and critical slope variables were retained in the final spring Chinook salmon model but were not retained in the steelhead trout model. As with steelhead, spring Chinook salmon redd densities and discharge were negatively correlated, with the exception of 2006, which had the highest observed spawning density for spring Chinook salmon and the second highest discharge during the time period (fig. $3 \mathrm{~b}$ ).

\section{Discussion}

Our models proved useful for predicting redd densities of steelhead trout and spring Chinook salmon in the Methow River watershed with the use of broad-scale, landscape-level predictors. Land cover type, flow type, and hatchery effect were the strongest predictors of redd density for both species. In both datasets, woody wetlands and emergent herbaceous wetland areas were predicted to have the highest density of redds.

Primary and secondary rock types were excluded from the best fitting models for both species. This contrasts with findings by Steel and others (2004). They reported alluvium to be a good predictor of redd density within the Willamette River watershed. Differences in basin geology may explain our different results. For example, the Willamette River watershed is located on the western slope of the Cascade Range, whereas the Methow River watershed is farther north and on the eastern slope of the Cascades. Although the Methow River watershed is typical of glacial basins, the Willamette River watershed uniquely consists of massive alluvial deposits made during the catastrophic Missoula Floods. Bedrock formations of the two basins are quite different as well.

Models for both species predicted redds in reaches where they were not observed. This could be attributed to three potential reasons: (1) low spawner abundance; (2) observational error in redd counts; or (3) inter-annual variations (that is, between redd count methods). The current (2013) population level of both species is relatively low; thus, all potential spawning habitat is unlikely to be used. In spite of this, some areas are observed to have extremely high redd densities. In these areas, redd superimposition might be occurring, suggesting that the models did not capture ecological or behavioral preferences that have evolved over the past 5,000 years (Waples and others, 2008). Preferences for these areas are likely driven by fine-scale environmental cues that we were not able to include in the modeling process due to the scale of our modeling. However, the models performed very well at the watershed level.

Besides the issue of low spawner abundance, redd counting errors also may have contributed to error in our model predictions. As an estimate of the total number of redds constructed in a reach, redd counts tend to be negatively biased for a number of reasons (Gallagher and Gallagher, 2005; Muhlfeld and others, 2006; Jones, 2012). For instance, the number of redds that remain observable and available to be counted is expected to be lower in years with higher discharge, due to geomorphic processes of scour and entombment (Jones, 2012). The strong linear relationship between mean annual discharge and the observed densities of steelhead trout redds (fig. 3a) generally supports this hypothesis. If the 2006 data point is removed for spring Chinook salmon, a similar pattern is evident (fig. 3b). During high-flow years, redds may not have been as visible, and consequently, not counted. Thus, imperfect detection of redds could result in redds being predicted where none were observed. In addition, redd densities were not correlated with number of spawners passing over Wells Dam during the study years, which suggests the possibility of observational error. 
Redd densities of both species were influenced by hatcheries, and the hatchery effect was retained in both models. The flow types associated with these areas, for example, manmade ditches or canals, contributed to the positive relationship between medium developed areas and redd densities (tables 5 and 8). Wild fish would likely not choose these areas or at least not use them to such a high degree.

Although we did not explicitly model hyporheic flow, the sinuosity term may capture some of this effect due to the relationship between channel complexity and hyporheic flow (Shallin-Busch and others, 2013). Additionally, more complex or sinuous reaches have lower probability of experiencing scour events that may increase egg mortality (Montgomery and Buffington, 1997), thereby providing better spawning and rearing habitat. Sinuosity explained the least amount of variation in redd density for steelhead trout. In contrast, sinuosity was retained in the final model for spring Chinook salmon. This may be attributed to the differences in the spatial distribution of redd density. Few Chinook salmon redds were observed in the lower mainstem of the Methow River, whereas steelhead trout redds were observed in areas farther downstream in the watershed, which is much less sinuous than areas upstream (figs. 1 and 4).

The focus of this study was to use landscape-level variables to predict redd density in the Methow River watershed using readily available landscape-level data. The simplicity of our model will allow it to be incorporated into larger ecosystem-based modeling platforms. Although a more complex model could be developed to include locations of known springs, more precise habitat designations, and water temperature, our models captured the primary variables influencing redd density. Water temperature data over the years we examined at the spatial scale needed for our analysis are lacking, but data collection efforts have been recently enhanced. If sufficient data becomes available in the future, the addition of water temperature may improve model performance.

\section{Acknowledgments}

We would like to thank the numerous individuals responsible for conducting redd counts within the Methow River watershed. We thank Kyle Martens for data support. We thank Michael Newsom of Bureau of Reclamation for funding this research and providing valuable ideas and insightful suggestions. We also thank the two reviewers whose comments greatly improved this report.

\section{References Cited}

Akaike, H., 1973, Information theory as an extension of the maximum likelihood principle, in Petrov, B.N., and Csaki, F., eds., Information Theory-Proceedings of the Second International Symposium: Budapest, Akademiai Kiado, p. 267-281

Burnett, K.M., Reeves, G.H., Miller, D.J., Clarke, S., Vance-Bordland, K., and Christiansen, K., 2007, Distribution of salmon-habitat potential relative to landscape characteristics and implications for conservation: Ecological Applications, v. 17, p. 66-80.

Gallagher, S.P., and Gallagher, C.M., 2005, Discrimination of Chinook salmon, coho salmon, and steelhead redds and evaluation of the use of redd data for estimating escapement in several unregulated streams in northern California: North American Journal of Fisheries Management, v. 25 , p. 284-300. 
Geist, D.R., Jones, J., Murray, C.J., and Dauble, D.D., 2000, Suitability criteria analyzed at the spatial scale of redd clusters improved estimates of fall Chinook salmon (Oncorhynchus tshawytscha) spawning habitat use in the Hanford Reach, Columbia River: Canadian Journal of Fisheries and Aquatic Sciences, v. 57, p. 1,636-1,646.

Hughes, R.M., Wang, L., and Seelbach, P.W., eds., 2006, Landscape influences on stream habitats and biological assemblages - Proceedings of the symposium on influences of landscape on stream habitat and biological communities held in Madison, Wisconsin, USA, August 25-26, 2004: Bethesda, Maryland, American Fisheries Society, 697 p.

Jones, E.C., 2012, Environmental stochasticity and the reliability of redd count data-A simulation study of redd construction, redd loss and survey frequency in a small coastal stream in Northern California: Humboldt, Humboldt State University, M.S. thesis, 85 p., 11 figs.

Konrad, C.P., Drost, B.W., and Wagner, R.J., 2003, Hydrogeology of the unconsolidated sediments, water quality, and ground-water/surface-water exchanges in the Methow River Basin, Okanogan County, Washington: U.S. Geological Survey Water-Resources investigations report 03-4244, $137 \mathrm{p}$.

Ludington, S., Moring, B.C., Miller, R.J., Stone, P.A., Bookstrom, A.A., Bedford, D.R., Evans, J.G., Haxel, G.A., Nutt, C.J., Flyn, K.S., Hopkins, M.J., 2005, Preliminary integrated geologic map databases for the United States, western states: California, Nevada, Arizona, Washington, Oregon, Idaho, and Utah: U.S. Geological Survey Open File Report 2005-1305, 1 p. [URL http://pubs.usgs.gov/of/2005/1305/].

Miller, D.J., Burnett, K.M., and Benda, L.E., 2008, Factors controlling availability of spawning habitat for salmonids at the basin scale in Sear, D., and DeVries, P., eds., Salmon spawning habitat in rivers, physical controls, biological responses and approaches to remediation: Bethesda, Md., American Fisheries Society, p. 103-120.

Montgomery, D.R., and Buffington, J.M., 1997, Channel-reach morphology in mountain drainage basins: Geological society of America Bulletin, v. 109, p. 596-611.

Montgomery, D.R., Buffington, J.M., Peterson, N.P., Schuett-Hames, D., and Quinn, T.P, 1996, Stream-bed scour, egg burial depths, and the influence of salmonid spawning on bed surface mobility and embryo survival: Canadian Journal of Fisheries and Aquatic Sciences, v. 53, p. 1,061-1,070.

Muhlfeld, C.C., Taper, M.L., Staples, D.F., and Shepard, B.B., 2006, Observer error structure in bull trout redd counts in Montana streams-Implications for inference on true redd numbers: Transactions of the American Fisheries Society, v. 135, p. 643-654.

National Marine Fisheries Service, 1999, Evaluations of the status of Chinook and chum salmon and steelhead hatchery populations for ESUs identified in final listing determinations: National Marine Fisheries Service-Northwest Fisheries Science Center status review update memorandum.

R Development Core Team, 2011, R-A language and environment for statistical computing: Vienna, Austria, R Foundation for Statistical Computing, ISBN 3-900051-07-0, accessed July 12, 2011, at http://www.R-project.org/.

Schwarz, G., 1978, Estimating the dimension of a model: The Annals of Statistics. v. 6, p. 461464.

Shallin-Busch, D., Sheer, M., Burnett, K., McElhany, P., and Cooney, T., 2013, Landscape-level model to predict spawning habitat for Lower Columbia River fall Chinook salmon (Oncorhynchus tshawytscha): River Research and Applications, v. 29, p. 297-312. 
Snow, C., Frady, C., Repp, A., Murdoch, A., Blankenship, S.M., Bowman, C., Small, M.P., Von Bargen, J., and Warheit, K.I., 2009, Monitoring and evaluation of Wells and Methow hatchery programs in 2008: Douglas County Public Utility District and Wells Habitat Conservation Plan Hatchery Committee, $83 \mathrm{p}$.

Steel, E.A., Feist, B.E., Jensen, D.W., Pess, G.R., Sheer, M.B., Brauner, J.B., and Bilby, R.E., 2004, Landscape models to understand steelhead (Oncorhynchus mykiss) distribution and help prioritize barrier removals in the Willamette basin, Oregon, USA: Canadian Journal of Fisheries and Aquatic Sciences, v. 61, p. 999-1,011.

Stoffel, K.L., Joseph, N.L., Waggoner, S.Z., Gulick, C.W., Korosec, M.A., and Bunning, B.B., 1991, Geologic map of Washington-Northeast quadrant: Washington Division of Geology and Earth Resources, Geologic Map GM-39.

Fry, J., Xian, G., Jin, S., Dewitz, J., Homer, C., Yang, L., Barnes, C., Herold, N., and Wickham, J., 2011, Completion of the 2006 National Land Cover Database for the Conterminous United States, PE\&RS, v. 77, p. 858-864.

U.S. Geological Survey, U.S. Environmental Protection Agency and other State and local partners, 2011, National hydrography dataset (NHD): U.S. Geological Survey, accessed March 19, 2012, at http://nhd.usgs.gov/index.html.

Waitt, R.B., Jr., 1972, Geomorphology and glacial geology of the Methow drainage basin, eastern North Cascade Range, Washington: Seattle, University of Washington Ph.D. thesis, $154 \mathrm{p}$.

Waples, R.S., Pess, G.R., and Beechie, T., 2008, Evolutionary history of Pacific salmon in dynamic environments: Evolutionary Applications, v. 1, p. 189-206.

Zuur, A.F., Ieno, E.N., Walker, N.J., Saveliev, A.A., and Smith, G.M., 2009, Mixed effects models and extensions in ecology with R (1st ed.): New York, Springer, 574 p. 


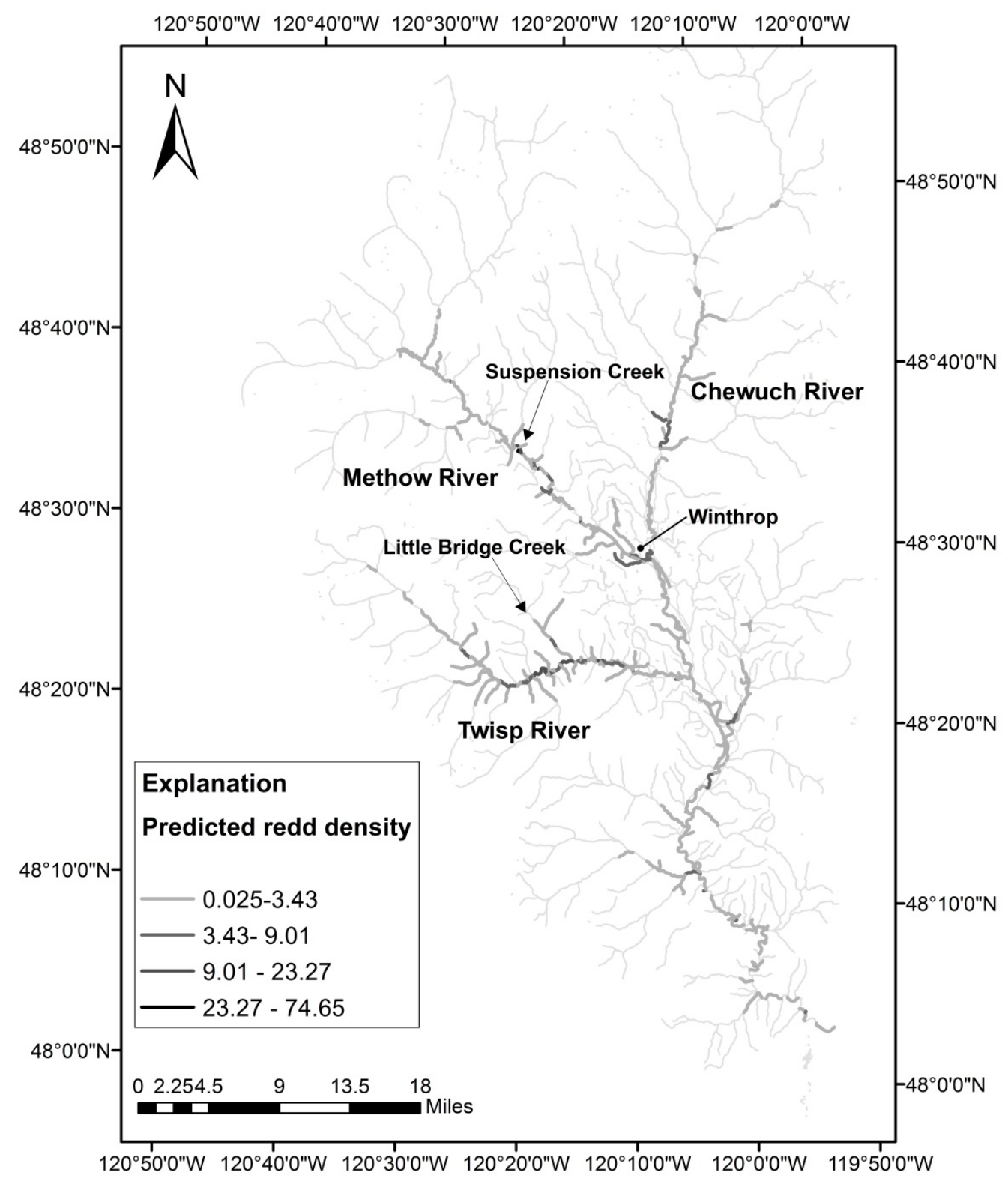

Figure 1. Predicted mean annual redd density (redds per kilometer) for steelhead trout in the Methow River watershed, Washington. 


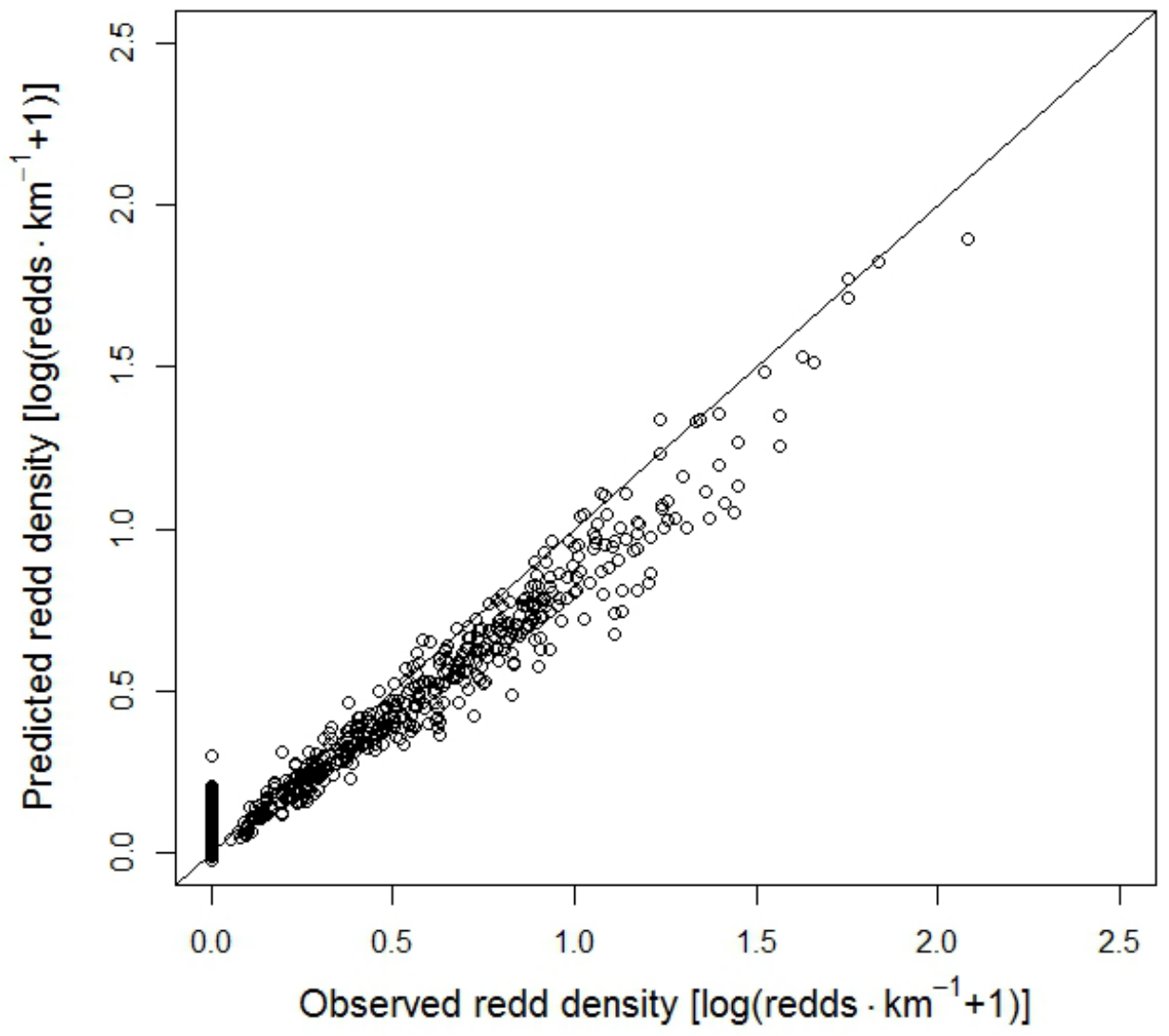

Figure 2. Predicted and observed redd densities for steelhead trout, Method River watershed, Washington, 2005-07 and 2009. Solid diagonal line shows where predicted redd density is equal to observed redd density. 
a)

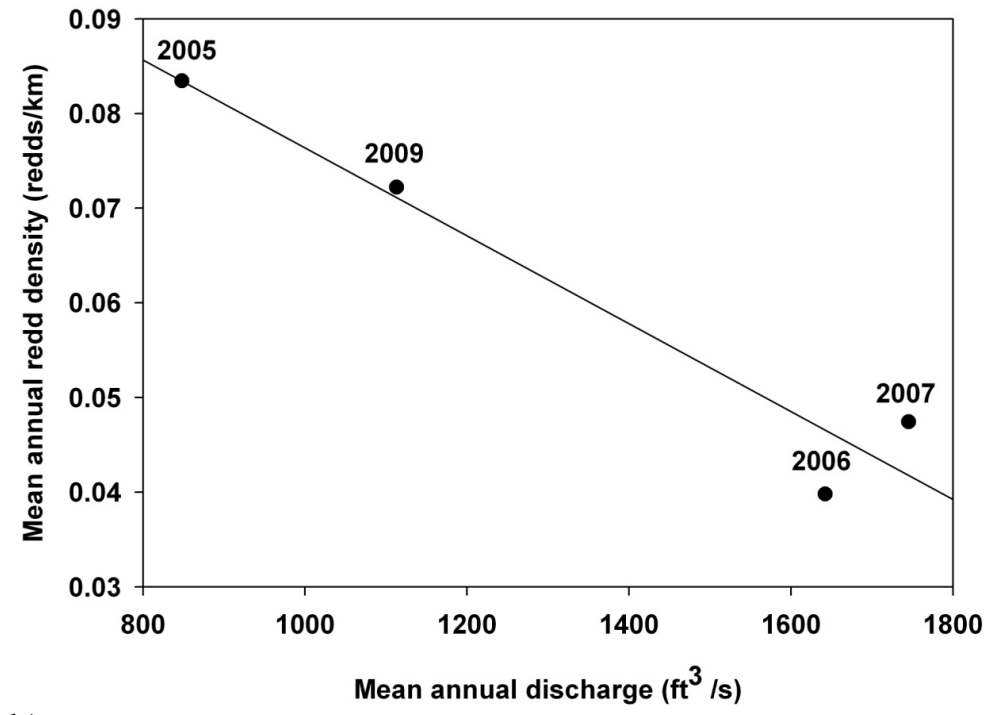

b)

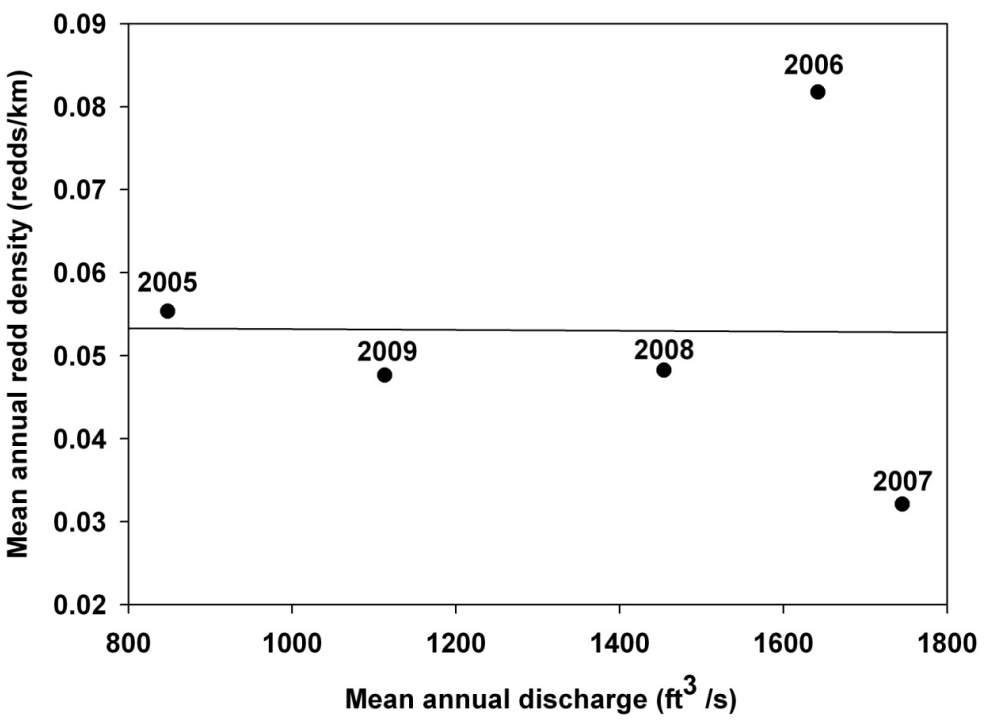

Figure 3. Relationship (solid black lines) between mean annual discharge of the Methow River at Twisp, Wash. (U.S. Geological Survey stream gage No. 12449500) and observed mean annual redd densities for (a) steelhead trout, and (b) spring Chinook salmon. Linear regression for steelhead trout was significant $\left(r^{2}=0.907, P=0.032\right)$. Linear regression for spring Chinook salmon was not significant $\left(r^{2}<0.001, P=0.987\right)$. $\mathrm{ft} 3 / \mathrm{s}$, cubic feet per second; redds/km, redds per kilometer. 


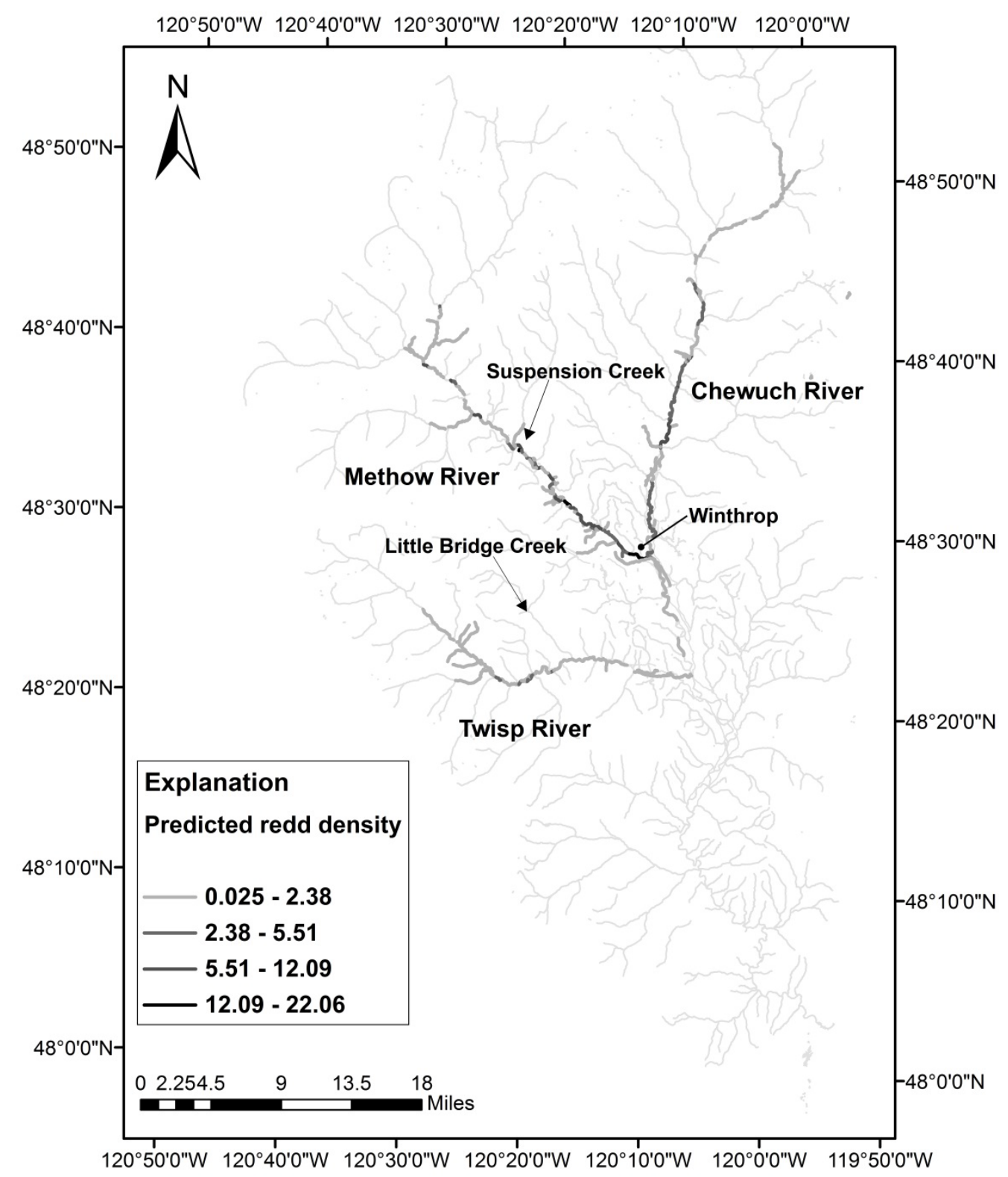

Figure 4. Predicted mean annual redd density (redds per kilometer) for spring Chinook salmon in the Methow River watershed, Washington. 


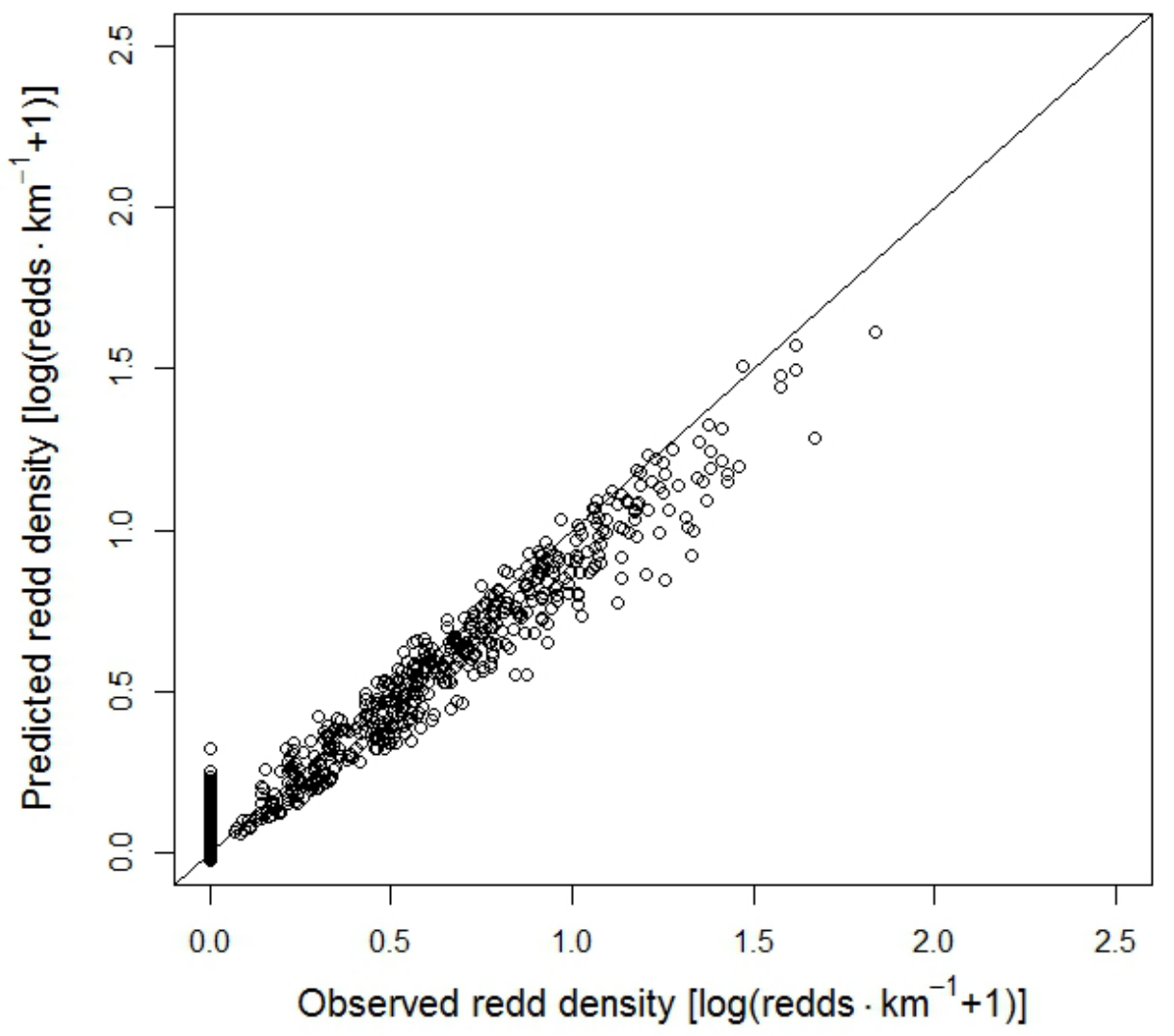

Figure 5. Predicted and observed redd densities for spring Chinook salmon, Methow River watershed, Washington, 2005-09.Solid diagonal line has a slope of 1 and intercept of 0 . 
Table 1. Water body characteristics for the Methow River watershed, Washington.

[National Hydrography data from U.S. Geological Survey and others (2011). FCODE is the numerical value for each flow type]

\begin{tabular}{lllr}
\hline FCODE & \multicolumn{1}{c}{ Flow type } & \multicolumn{1}{c}{ Description } & $\begin{array}{c}\text { Number of } \\
\text { reaches }\end{array}$ \\
\hline 33400 & Connector & None & 2 \\
33600 & Canal/Ditch & None & 256 \\
33601 & Canal/Ditch & Aqueduct & 1 \\
42807 & Pipeline & Surface to underground & 3 \\
42813 & Pipeline & Siphon & 2 \\
46000 & Stream/River & None & 1 \\
46003 & Stream/River & Intermittent & 12,326 \\
46006 & Stream/River & Perennial & 3,935 \\
55800 & Artificial Path & None & 1,641 \\
\hline
\end{tabular}

Table 2. Characteristics used to determine land cover type for each reach, Methow River watershed, Washington.

[National land cover data from U.S. Geological Survey (2011)]

\begin{tabular}{llr}
\hline $\begin{array}{c}\text { General land } \\
\text { cover type }\end{array}$ & \multicolumn{1}{c}{$\begin{array}{c}\text { Specific land } \\
\text { cover type }\end{array}$} & $\begin{array}{c}\text { Number of } \\
\text { reaches }\end{array}$ \\
\hline Water areas & Open water & 173 \\
\hline Developed & Open space & 16 \\
& Low intensity & 106 \\
& Medium intensity & 21 \\
& High intensity & 1 \\
\hline Barren & Barren land & 38 \\
\hline Forest areas & Deciduous & 2 \\
& Evergreen & 3,790 \\
\hline Shrubland areas & Shrub/scrub & 4,989 \\
\hline Herbaceaous areas & Grassland/herbaceous & 1,187 \\
\hline Cultivated areas & Pasture/hay & 33 \\
& Cultivated crops & 14 \\
\hline Wetlands & Woody wetlands & 102 \\
& Emergent herbaceous wetlands & 17 \\
\hline
\end{tabular}


Table 3. Primary (a) and secondary (b) rock types and associated number of reaches for the Methow River watershed, Washington.

(a)

\begin{tabular}{lr}
\hline \multicolumn{1}{c}{ Dominant primary rock type } & $\begin{array}{c}\text { Number of } \\
\text { reaches }\end{array}$ \\
\hline Alluvium & 1,100 \\
Andesite & 1,796 \\
Arkose & 1,434 \\
Basalt & 8 \\
Biotite gneiss & 1,277 \\
Granite & 3,318 \\
Granodiorite & 281 \\
Llatite & 56 \\
Phyllite & 56 \\
Quartz diorite & 19 \\
Quartz monzodiorite & 69 \\
Sandstone & 32 \\
Schist & 1,030 \\
Water & 13 \\
\hline
\end{tabular}

(b)

\begin{tabular}{lc}
\hline \multicolumn{1}{c}{ Dominant secondary rock type } & $\begin{array}{c}\text { Number of } \\
\text { reaches }\end{array}$ \\
\hline Alluvial terrace & 4,400 \\
Amphibole schist & 328 \\
Andesite & 396 \\
Black shale & 1,600 \\
Gneiss & 4,508 \\
Granite & 1,212 \\
Granodiorite & 13,644 \\
Orthogneiss & 4,876 \\
Sandstone & 6,840 \\
Schist & 0 \\
Shale & 884 \\
Siltstone & 3,032 \\
Tonalite & 68 \\
Volcanic breccia (agglomerate) & 128 \\
\hline
\end{tabular}


Table 4. Single-variable mixed models fit to steelhead trout redd data, Methow River watershed, Washington.

[DF, degrees of freedom. BIC, Bayesian Information Criterion. -LL, Negative log likelihood. $\Delta$ BIC, change in $\mathrm{BIC}]$

\begin{tabular}{lrrrrrr}
\hline \multicolumn{1}{c}{ Model } & Parameters & $\begin{array}{c}\text { Numerator } \\
\text { DF }\end{array}$ & $\begin{array}{c}\text { Denominator } \\
\text { DF }\end{array}$ & BIC & -LL & \multicolumn{1}{c}{$\boldsymbol{\Delta B I C}$} \\
\hline Spring effect & 5 & 1 & 10,474 & $-115,705$ & $-57,922$ & 0 \\
Flow type & 7 & 3 & 10,472 & $-114,796$ & $-57,478$ & 909 \\
Hatchery effect & 5 & 1 & 10,474 & $-114,536$ & $-57,337$ & 1,168 \\
Critical slope & 5 & 1 & 10,474 & $-114,027$ & $-57,083$ & 1,677 \\
Mean slope & 5 & 1 & 10,474 & $-113,940$ & $-57,039$ & 1,765 \\
Land cover type & 17 & 13 & 10,462 & $-113,938$ & $-57,102$ & 1,767 \\
Year & 4 & 3 & 31,425 & $-113,789$ & $-56,974$ & 1,916 \\
Secondary rock type & 16 & 12 & 10,463 & $-113,769$ & $-57,012$ & 1,936 \\
Sinuosity & 5 & 1 & 10,474 & $-113,745$ & $-56,942$ & 1,960 \\
Primary rock type & 17 & 13 & 10,462 & $-113,741$ & $-57,004$ & 1,963 \\
Intercept only & 1 & 1 & 31,428 & $-113,739$ & $-56,934$ & 1,965 \\
\hline
\end{tabular}


Table 5. Model coefficient values for each variable in the best fit model for steelhead trout, Methow River watershed, Washington.

[SE, standard error]

\begin{tabular}{|c|c|c|c|}
\hline Variable & Coefficient & SE & $p$-value \\
\hline (Intercept) & -0.0833 & 0.0081 & $<0.001$ \\
\hline Year2006 & -0.0050 & 0.0007 & $<0.001$ \\
\hline Year2007 & -0.0051 & 0.0008 & $<0.001$ \\
\hline Year2009 & -0.0005 & 0.0008 & 0.543 \\
\hline Hatchery effect & 0.3567 & 0.0287 & $<0.001$ \\
\hline Spring effect & 1.3700 & 0.0352 & $<0.001$ \\
\hline \multicolumn{4}{|l|}{ Land cover type } \\
\hline Developed open space & 0.0826 & 0.0124 & $<0.001$ \\
\hline Developed low intensity & 0.1034 & 0.0062 & $<0.001$ \\
\hline Developed medium intensity & 0.1486 & 0.0106 & $<0.001$ \\
\hline Developed high intensity & -0.0239 & 0.0452 & 0.597 \\
\hline Barren land & 0.1102 & 0.0083 & $<0.001$ \\
\hline Deciduous forest & 0.0995 & 0.0321 & 0.002 \\
\hline Evergreen forest & 0.1015 & 0.0045 & $<0.001$ \\
\hline Shrub/scrub & 0.0995 & 0.0045 & $<0.001$ \\
\hline Grassland & 0.0990 & 0.0047 & $<0.001$ \\
\hline Pasture & 0.0845 & 0.0089 & $<0.001$ \\
\hline Cultivated crops & 0.0965 & 0.0129 & $<0.001$ \\
\hline Woody wetlands & 0.1189 & 0.0060 & $<0.001$ \\
\hline Emergent herbaceous wetlands & 0.1265 & 0.0115 & $<0.001$ \\
\hline \multicolumn{4}{|l|}{ Flow type } \\
\hline Intermittent & -0.0113 & 0.0067 & 0.093 \\
\hline Perennial & -0.0051 & 0.0069 & 0.456 \\
\hline Artificial & 0.1120 & 0.0073 & $<0.001$ \\
\hline
\end{tabular}


Table 6. Model selection results for mixed models predicting steelhead trout redd density, Methow River watershed, Washington.

[All models fitted to the data that converged are listed in the table. Year was included as random slope and reach as random intercept. Best fit model is the model with lowest BIC score. AIC, Akaike Information Criterion. BIC, Bayesian Information Criterion. -LL, Negative log likelihood. $\mathbf{B I C}$, change in BIC; $\triangle \mathrm{AIC}$, change in AIC]

\begin{tabular}{|c|c|c|c|c|c|}
\hline Model & AIC & $\mathrm{BIC}$ & $-\mathrm{LL}$ & $\Delta \mathrm{AIC}$ & $\Delta \mathrm{BIC}$ \\
\hline Year+Land Cover Type+ Flow Type+ & & & & & \\
\hline Hatchery Effect+Spring Effect & $-117,754$ & $-117,469$ & $-58,910$ & 0 & 0 \\
\hline $\begin{array}{l}\text { Year+Critical Slope }+ \text { Secondary Rock Type } \\
\text { Land Cover Type+ Flow Type }+\end{array}$ & & & & & \\
\hline Hatchery Effect+Spring Effect & $-117,815$ & $-117,417$ & $-58,953$ & -61 & 52 \\
\hline $\begin{array}{l}\text { Year+Mean Slope+Critical Slope+Sinuosity } \\
\text { Secondary Rock Type+Land Cover Type+ }\end{array}$ & & & & & \\
\hline Flow Type + Hatchery Effect + Spring Effect & $-117,816$ & $-117,404$ & $-58,956$ & -62 & 65 \\
\hline
\end{tabular}

Table 7. Single -variable models fit to spring Chinook salmon data, Methow River watershed, Washington.

[AIC, Akaike Information Criterion. BIC, Bayesian Information Criterion. -LL, negative log likelihood. $\triangle$ AIC, change in AIC. $\triangle \mathrm{BIC}$, change in BIC]

\begin{tabular}{lrrrrr}
\hline \multicolumn{1}{c}{ Model } & AIC & BIC & -LL & $\Delta$ AIC & ABIC \\
\hline Flow type & $-164,916$ & $-164,739$ & $-82,478$ & 0 & 0 \\
Critical slope & $-163,993$ & $-163,834$ & $-82,015$ & 923 & 905 \\
Mean slope & $-163,881$ & $-163,722$ & $-81,959$ & 1,034 & 1,017 \\
Habitat type & $-163,983$ & $-163,717$ & $-82,021$ & 933 & 1,022 \\
Hatchery effect & $-163,846$ & $-163,687$ & $-81,941$ & 1,069 & 1,052 \\
Spring effect & $-163,657$ & $-163,497$ & $-81,846$ & 1,259 & 1,241 \\
Sinuosity & $-163,647$ & $-163,488$ & $-81,842$ & 1,269 & 1,251 \\
Intercept only & $-163,611$ & $-163,460$ & $-81,822$ & 1,305 & 1,279 \\
Year & $-163,640$ & $-163,453$ & $-81,841$ & 1,276 & 1,285 \\
Secondary rock type & $-163,707$ & $-163,450$ & $-81,882$ & 1,209 & 1,289 \\
Primary rock type & $-163,682$ & $-163,416$ & $-81,871$ & 1,234 & 1,323 \\
\hline
\end{tabular}


Table 8. Model coefficient values for each variable in the best fit model for spring Chinook salmon, Methow River watershed, Washington.

[SE, standard error]

\begin{tabular}{lccc}
\hline \multicolumn{1}{c}{ Variable } & Coefficient & SE & p-value \\
\hline (Intercept) & -0.1072 & 0.0131 & $<0.001$ \\
Sinuosity & -0.0396 & 0.0098 & $<0.001$ \\
Critical slope & 0.0131 & 0.0024 & $<0.001$ \\
Hatchery effect & 0.4041 & 0.0279 & $<0.001$ \\
Land cover type & & & \\
Developed open space & 0.1167 & 0.0132 & $<0.001$ \\
Developed low intensity & 0.1317 & 0.0066 & $<0.001$ \\
Developed. medium intensity & 0.1802 & 0.0113 & $<0.001$ \\
Developed high intensity & -0.0187 & 0.0480 & 0.697 \\
Barren land & 0.1346 & 0.0089 & $<0.001$ \\
Deciduous forest & 0.1350 & 0.0342 & $<0.001$ \\
Evergreen forest & 0.1402 & 0.0048 & $<0.001$ \\
Shrub/scrub & 0.1383 & 0.0048 & $<0.001$ \\
Grassland & 0.1395 & 0.0050 & $<0.001$ \\
Pasture & 0.1165 & 0.0095 & $<0.001$ \\
Cultivated crops & 0.1304 & 0.0137 & $<0.001$ \\
Woody wetlands & 0.1740 & 0.0064 & $<0.001$ \\
Emergent herbaceous wetlands & 0.2047 & 0.0123 & $<0.001$ \\
Flow type & & & \\
Intermittent & 0.0018 & 0.0072 & 0.805 \\
Perennial & 0.0043 & 0.0073 & 0.556 \\
Artificial & 0.1489 & 0.0078 & $<0.001$ \\
\hline
\end{tabular}


Table 9. Model selection results for mixed models predicting spring Chinook salmon redd density, Methow River watershed, Washington.

[All models fitted to the data that converged are listed in the table. Year was included as random slope and reach as random intercept. Best fit model is model with lowest BIC score. AIC, Akaike Information Criterion. BIC, Bayesian Information Criterion, -LL, Negative log likelihood. $\Delta$ AIC, change in AIC. $\triangle \mathrm{BIC}$, change in BIC]

\begin{tabular}{lccccc}
\hline \multicolumn{1}{c}{ Model } & AIC & BIC & -LL & $\Delta$ AIC & $\Delta$ BIC \\
\hline $\begin{array}{l}\text { Sinuosity+Critical Slope+Land Cover Type+ } \\
\text { Flow Type+Hatchery Effect }\end{array}$ & $-166,183$ & $-165,864$ & $-83,127$ & 0 & 0 \\
$\begin{array}{l}\text { Year+Sinuosity+Critical Slope+ } \\
\text { Secondary Rock Type+Land Cover Type+ }\end{array}$ & & & & & \\
Flow Type+ Hatchery Effect & $-166,222$ & $-165,761$ & $-83,163$ & -39 & 103 \\
$\begin{array}{l}\text { Year+Mean Slope+Critical Slope+Sinuosity+ } \\
\text { Secondary Rock Type+Land Cover Type+ } \\
\text { Flow Type+ Hatchery Effect+Spring Effect }\end{array}$ & $-166,224$ & $-165,745$ & $-83,166$ & -41 & 119 \\
\hline
\end{tabular}


This page left intentionally blank 
Publishing support provided by the U.S. Geological Survey Publishing Network, Tacoma Publishing Service Center

For additional information contact:

Director, Western Fisheries Research Center

U.S. Geological Survey

6505 NE 65th Street

Seattle, Washington 98115

http://wfrc.usgs.gov/ 


\section{总}

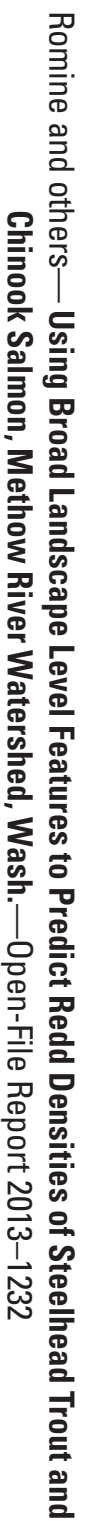

